\title{
Silicon Accumulation and Distribution in Petunia and Sunflower Grown in a Rice Hull-amended Substrate
}

\author{
Jennifer K. Boldt ${ }^{1}$ and James C. Locke \\ USDA-ARS, Application Technology Research Unit, Greenhouse Production \\ Research Group, 2801 W. Bancroft Street, Mail Stop 604, Toledo, OH 43606
}

\author{
James E. Altland \\ USDA-ARS, Application Technology Research Unit, 1680 Madison Avenue, \\ Wooster, OH 44691
}

Additional index words. Petunia $\times$ hybrida, Helianthus annuus, floriculture

\begin{abstract}
Silicon (Si) is a plant beneficial element associated with the mitigation of abiotic and biotic stresses. Most greenhouse-grown ornamentals are considered low $\mathrm{Si}$ accumulators based on foliar Si concentration. However, Si accumulates in all tissues, and there is little published data on the distribution of $\mathrm{Si}$ in plants. This knowledge may be critical to using Si to mitigate tissue-specific plant stresses, e.g., pathogens. Therefore, we quantified Si accumulation and distribution in petunia (Petunia $\times$ hybrida Hort. Vilm.Andr. 'Dreams Pink'), a low Si accumulator, and sunflower (Helianthus annuus $\mathbf{L}$. 'Pacino Gold'), a high Si accumulator. Plants were grown in a sphagnum peat: perlite substrate amended with $0 \%(-\mathrm{Si})$ or $20 \%(+\mathrm{Si})$ parboiled rice hulls for 53 (petunia) or 72 days (sunflower). Aboveground dry weight was greater in nonamended petunia $(13 \%)$ and sunflower $(\mathbf{1 8 \%})$, compared with rice hull-amended plants, but days to flower was unaffected. Sunflowers grown in the rice hull-amended substrate had the greatest $\mathrm{Si}$ concentration in leaves $\left(10,909 \mathrm{mg} \cdot \mathrm{kg}^{-1}\right)$, whereas roots $\left(895 \mathrm{mg} \cdot \mathrm{kg}^{-1}\right)$, stems $(303$ $\left.\mathrm{mg} \cdot \mathrm{kg}^{-1}\right)$, and flowers $\left(252 \mathrm{mg} \cdot \mathrm{kg}^{-1}\right)$ had lower, but similar Si concentrations. In petunia, Si concentration was greatest in leaves $\left(2036 \mathrm{mg} \cdot \mathrm{kg}^{-1}\right)$, then roots $\left(1237 \mathrm{mg} \cdot \mathrm{kg}^{-1}\right)$, followed by stems $\left(301 \mathrm{mg} \cdot \mathrm{kg}^{-1}\right)$, and flowers $\left(247 \mathrm{mg} \cdot \mathrm{kg}^{-1}\right)$. The addition of rice hulls to the substrate increased Si concentration in sunflower $414 \%$ in roots, $512 \%$ in flowers, $611 \%$ in stems, and $766 \%$ in leaves. By contrast, Si concentration in petunia increased only $7 \%$ in flowers, $105 \%$ in stems, and $115 \%$ in leaves, but increased $687 \%$ in roots. In rice hull-amended sunflowers, the distribution of $\mathrm{Si}$ was $91 \%$ in leaves, $3 \%$ in stems, $3 \%$ in roots, and $3 \%$ in flowers, and in petunia, it was $72 \%$ in leaves, $17 \%$ in stems, $6 \%$ in roots, and $5 \%$ in flowers.
\end{abstract}

Silicon is a plant beneficial element. It is associated with several positive physiological responses in plants (Ma, 2004), including reduced lodging (Ma and Yamaji, 2006; Savant et al., 1999), increased stem diameter (Kamenidou et al., 2008), higher rates of photosynthesis (Liang et al., 1996; RomeroAranda et al., 2006), increased dry weight (Liang et al., 1996; Romero-Aranda et al., 2006), increased yield (Savant et al., 1999), increased flower size (Kamenidou et al., 2010), and earlier flowering (Boldt et al., 2015). Silicon has been shown to mitigate the impacts of many biotic and abiotic stresses, including powdery mildews (e.g., Blumeria graminis f. sp. tritici, Erysiphe cichoracearum, and Sphaerotheca fulginea) (Chain

Received for publication 21 July 2017. Accepted for publication 5 Dec. 2017.

Mention of trade names or commercial products in this publication is solely for the purpose of providing specific information and does not imply recommendation or endorsement by the U.S. Department of Agriculture. USDA is an equal opportunity provider and employer.

${ }^{1}$ Corresponding author. E-mail: jennifer.boldt@ ars.usda.gov. [cucumber (Cucumis sativus L.), squash, and pumpkin (Cucurbita spp.)], and Asteraceae [sunflower and zinnia (Zinnia elegans L.)] are Si accumulators (Frantz et al., 2010). However, most greenhouse-grown ornamentals are considered low $\mathrm{Si}$ accumulators or nonaccumulators. Frantz et al. (2010) grew 48 horticultural crops hydroponically in a modified Hoagland's solution amended with $1 \mathrm{~mm} \mathrm{Si}$ and quantified foliar Si concentration. It ranged between 102 and 12,682 $\mathrm{mg} \cdot \mathrm{kg}^{-1} \mathrm{Si}$ [ornamental tobacco (Nicotiana sylvestris Speg. \& Comes.) and zinnia, respectively], and more than half the species accumulated less than $1000 \mathrm{mg} \cdot \mathrm{kg}^{-1} \mathrm{Si}$.

For many years, it has been debated as to whether Si supplementation would be beneficial to nonaccumulators, because they do not accumulate high foliar concentrations (Ma et al., 2001; Mitani and Ma, 2005). The role of $\mathrm{Si}$ in plants may be both in a structural capacity and as a signaling compound (Fauteux et al., 2006), and therefore, nonaccumulators could still benefit from $\mathrm{Si}$ supplementation and increased $\mathrm{Si}$ accumulation following imposition of a stress. For example, the addition of Si to the hydroponic nutrient solution delayed Tobacco ringspot virus symptom formation and reduced symptomatic leaf area in tobacco (Nicotiana tabacum L.) (Zellner et al., 2011), and it ameliorated copper $(\mathrm{Cu})$ toxicity in arabidopsis [Arabidopsis thaliana L. (Heynh.)] (Li et al., 2008) and snapdragon (Antirrhinum majus L.) (Frantz et al., 2011), all Si nonaccumulators.

Soluble, plant-available Si can be supplied through substrate components, substrate amendments, liquid fertilization, or foliar sprays. Silicon is absorbed by plants primarily via the roots through passive or active uptake (Liang et al., 2006; Mitani and Ma, 2005). Plants accumulate Si in all tissues, although some may accumulate high $\mathrm{Si}$ concentrations in roots, and perhaps other tissues, but not in foliage. Recent studies have shown that root $\mathrm{Si}$ fractions in nonaccumulators may be as high as, or higher than, in Si accumulators. For example, we detected low foliar Si concentrations (1473 $\mathrm{mg} \cdot \mathrm{kg}^{-1}$ ) but higher root $\mathrm{Si}$ concentrations (2000-7000 $\mathrm{mg} \cdot \mathrm{kg}^{-1}$ ) in rose (Rosa 'Radrazz') plants grown at low P (2.5-20 $\mathrm{mg} \cdot \mathrm{L}^{-1}$; J.E. Altland and J.K. Boldt, unpublished data). Differences in root and shoot $\mathrm{Si}$ concentrations may result from differential regulation of $\mathrm{Si}$ uptake, the mechanism of xylem loading (active or passive), transporter concentration, or the stress status of a plant (Liang et al., 2006; Mitani and Ma, 2005).

There is little published research on the distribution of $\mathrm{Si}$ in plants. For species in which it has been documented, $\mathrm{Si}$ is not uniformly distributed throughout the plant. Rice grown in nutrient solution with $150 \mathrm{ppm}$ $\mathrm{SiO}_{2}\left(70 \mathrm{mg} \cdot \mathrm{L}^{-1} \mathrm{Si}\right)$ averaged $9800 \mathrm{mg} \cdot \mathrm{kg}^{-1}$ $\mathrm{Si}$ in roots, $57,000 \mathrm{mg} \cdot \mathrm{kg}^{-1}$ in leaf sheaths, and $63,000 \mathrm{mg} \cdot \mathrm{kg}^{-1}$ in leaf blades, on a dry weight basis, as calculated from values reported as $\% \mathrm{SiO}_{2}$ (Yoshida et al., 1962). In oat, Si ranged from $280 \mathrm{mg} \cdot \mathrm{kg}^{-1}$ in caryopses 
to $36,000 \mathrm{mg} \cdot \mathrm{kg}^{-1}$ in inflorescences, with more than $40 \%$ of total aboveground $\mathrm{Si}$ localized in inflorescences (Jones and Handreck, 1967). Kamenidou et al. (2008) compared the effects of different sources of Si supplementation on tissue Si concentration of sunflower 'Ring of Fire' grown in a peatbased soilless substrate, and although tissue concentrations were not compared within a treatment, reported that leaf Si concentrations $\left(4900-15,300 \mathrm{mg} \cdot \mathrm{kg}^{-1}\right)$ were greater than those in flowers $\left(3800-5100 \mathrm{mg} \cdot \mathrm{kg}^{-1}\right)$ or stems (2900-4200 mg. $\left.\mathrm{kg}^{-1}\right)$.

Knowledge of Si distribution in plants is critical for using Si to mitigate plant stresses that are tissue specific. For example, the common greenhouse pathogen botrytis (Botrytis cinerea) typically attacks flowers and leaves, whereas pythium (Pythium ultimum) causes root rot. If, for instance, flowers were found to contain appreciable quantities of $\mathrm{Si}$, follow-up studies could investigate whether the accumulation of $\mathrm{Si}$ can provide protection against fungal pathogens like botrytis and offer growers a nonpesticide alternative to include in their pest management rotation.

The objective of this study was to document $\mathrm{Si}$ distribution in greenhouse crops to better understand how it might (or might not) be useful for mitigating stress in these species. Specifically, the experiment was designed to evaluate $\mathrm{Si}$ accumulation and distribution in roots, leaves, stems, and flowers of plants, using parboiled rice hulls as the source of supplemental Si. Two species were selected: petunia, classified as a nonaccumulator of $\mathrm{Si}$, and sunflower, classified as a $\mathrm{Si}$ accumulator.

\section{Materials and Methods}

Sunflower 'Pacino Gold' and petunia 'Dreams Pink' (Ball Seed Co., West Chicago, IL) were sown in 288-count plug trays filled with soilless substrate (LB-2; Sun Gro Horticulture, Bellevue, WA) and germinated in a growth chamber (PGR-16; Conviron, Vancouver, BC) maintained at $22{ }^{\circ} \mathrm{C} \mathrm{d} / 18{ }^{\circ} \mathrm{C}$ night, $200 \mu \mathrm{mol} \cdot \mathrm{m}^{-2} \cdot \mathrm{s}^{-1}$ photosynthetic photon flux $(P P F)$ from cool-white fluorescent lamps, and an $8 \mathrm{~h}$ photoperiod. Plants were irrigated as needed with reverse osmosis (18 M 2 ) water until the first true leaves unfolded, then fertigated with 20N-4.4P-16.6K (Jacks 20-10-20; JR Peters, Inc., Allentown, PA) at a concentration of $50 \mathrm{mg} \cdot \mathrm{L}^{-1} \mathrm{~N}$. Reverse osmosis water was used to mix the fertilizer to minimize the addition of Si.

Seedlings of sunflower and petunia were transplanted on 10 Nov. and 16 Nov. 2015, respectively, into $11.5-\mathrm{cm}$ diameter plastic pots, one plant per pot. The soilless substrate was an 85: 15 blend of sphagnum peat (Sun Gro Horticulture, Seba Beach, AB, Canada) and medium grade coarse perlite (Sun Gro Horticulture) amended with $1.55 \mathrm{~kg} \cdot \mathrm{m}^{-3}$ laboratory-grade $\mathrm{CaCO}_{3}$ and $0.52 \mathrm{~kg} \cdot \mathrm{m}^{-3}$ $\mathrm{MgCO}_{3}$ (Fisher Scientific, Fair Lawn, NJ) and $0.196 \mathrm{~L} \cdot \mathrm{m}^{-3}$ of a wetting agent (SOAX; Smithers-Oasis, Kent, OH). Parboiled rice hulls (Riceland Foods, Inc., Stuttgart, AK) were incorporated at $0 \%$ or $20 \%$ (by volume). Total Si concentrations for the substrate, rice hulls, fertilizer, and irrigation water are listed in Table 1. Plants were grown in a glassglazed greenhouse (Toledo, $\mathrm{OH}$ ), with day/ night air temperature set points of $22 / 18{ }^{\circ} \mathrm{C}$, a $14 \mathrm{~h}$ photoperiod, and supplemental lighting from 1000-W high-pressure sodium lamps when ambient irradiance inside the greenhouse was less than $300 \mu \mathrm{mol} \cdot \mathrm{m}^{-2} \cdot \mathrm{s}^{-1}$ $P P F$. Mean day and night temperatures were $21.4 \pm 0.3{ }^{\circ} \mathrm{C}$ and $18.0 \pm 0.3{ }^{\circ} \mathrm{C}$, respectively, and mean daily light integral was $5.8 \pm$ $0.8 \mathrm{~mol} \cdot \mathrm{m}^{-2} \cdot \mathrm{d}^{-1}$.

Forty individual pots of each species, 20 per treatment, were arranged on a bench in a completely randomized design. Plants were fertigated as needed with $20 \mathrm{~N}-4.4 \mathrm{P}-16.6 \mathrm{~K}$ at a concentration of $150 \mathrm{mg} \cdot \mathrm{L}^{-1} \mathrm{~N}$. Date of first flower was recorded and days to flower were calculated. Petunia and sunflower were harvested on 8 Jan. and 21 Jan. 2016, respectively, once all plants had flowered. At harvest, the pour-through method (LeBude and Bilderback, 2009) was conducted and a $50 \mathrm{~mL}$ leachate sample was collected from each pot. Samples were stored at $4{ }^{\circ} \mathrm{C}$ until the following day, when $\mathrm{pH}$ and electrical conductivity (EC) were measured (HANNA HI9814 GroPro; Hanna Instruments, Woonsocket, RI). They were then frozen until they could be analyzed for nutrient concentration. After thawing, the leachates were filtered (Whatman \#2 filter paper; Whatman Ltd., Kent, UK). To determine Si concentration, $9.5 \mathrm{~mL}$ of $2.1 \%$ potassium hydroxide $(\mathrm{KOH})$ was added to a $0.5 \mathrm{~mL}$ aliquot of leachate, and the solution was analyzed using inductively coupled plasma optical emission spectroscopy (ICP-OES, iCAP 6300 Duo; Thermo Electron Corp., Waltham, MA). To determine leachate macro- and micronutrient concentrations, $9 \mathrm{~mL}$ of $3.89 \%$ nitric acid was added to a $1 \mathrm{~mL}$ aliquot of leachate, and the solution was analyzed using ICP-OES.

Flower number was recorded for petunia and included open and senesced flowers. Petunia and sunflower plants were harvested at the soil surface and divided into flowers, leaves, and stems. For petunia, flowers were defined as all floral organs except sepals, and included buds with petal coloration, open flowers, and senesced flowers. For sunflower, the primary inflorescence as well as any axillary inflorescences or buds with petal coloration were considered flowers. Leaves were detached at the base of the petiole. The stem component included stems, petioles, sepals (petunia only), and immature flower buds or inflorescences. Roots were gently washed in reverse osmosis $(18 \mathrm{M} \Omega$ ) water to remove the substrate. Each tissue was individually dipped in $0.1 \mathrm{M} \mathrm{HCl}$, rinsed in $18 \mathrm{M} \Omega$ water, and placed in a paper bag. Samples were placed in a forced air drying oven at $60{ }^{\circ} \mathrm{C}$ for $3 \mathrm{~d}$, and then weighed for dry weight. Each sample was ground individually for tissue elemental analysis using a mortar and pestle (flowers, leaves, and roots) or coffee grinder (stems).
Table 1. Total silicon (Si) concentration in the irrigation water, fertilizer, soilless substrate, and rice hulls used in this study.

\begin{tabular}{lc}
\hline Source & Total Si concn \\
\hline Reverse osmosis & $\mathrm{ND}^{\mathrm{z}}$ \\
$\quad$ water $(18 \mathrm{M} \Omega)$ & $\mathrm{ND}$ \\
Fertilizer $(20 \mathrm{~N}-4.4 \mathrm{P}-16.6 \mathrm{~K})$ & $23,109 \mathrm{mg} \cdot \mathrm{kg}^{-1}$ \\
85 sphagnum peat: & \\
$\quad 15$ perlite substrate & \\
Parboiled rice hulls & \\
$\mathrm{z}_{<}<.01 \mathrm{mg} \cdot \mathrm{L}^{-1} \cdot$ & \\
${ }^{\mathrm{y}}$ Formulated on a volume basis. & \\
$\mathrm{ND}=$ not detected. &
\end{tabular}

Foliar nitrogen $(\mathrm{N})$ was determined by measuring $\approx 2.5 \mathrm{mg}$ of dry tissue into tin capsules (Costech Analytical, Valencia, CA) and analyzing with a $\mathrm{CHN}$ analyzer (vario MICRO cube; Elementar, Hanau, Germany). Remaining elements were determined using ICP-OES. For all macronutrients and micronutrients except $\mathrm{N}$ and $\mathrm{Si}, \approx 0.25 \mathrm{~g}$ of dry tissue was placed in a Teflon vessel and $5 \mathrm{~mL}$ of nitric acid was added. Samples were heated in a programmable microwave (MARS 6; CEM Corp., Matthews, NC) by ramping the temperature up to $200{ }^{\circ} \mathrm{C}$ over $15 \mathrm{~min}$, maintaining $200{ }^{\circ} \mathrm{C}$ for $15 \mathrm{~min}$, and then cooling to room temperature. Next, $1.5 \mathrm{~mL}$ of hydrogen peroxide was added, solutions were reheated to $200{ }^{\circ} \mathrm{C}$ and maintained for an additional $5 \mathrm{~min}$. After cooling, $12 \mathrm{~mL}$ of 18 $\mathrm{M} \Omega$ water was added and the solutions were filtered (Whatman \#2). A $1.3 \mathrm{~mL}$ aliquot of solution was diluted with $8.7 \mathrm{~mL} 18 \mathrm{M} \Omega$ water and analyzed using ICP-OES.

Analysis of tissue for $\mathrm{Si}$ concentration followed a similar procedure to that described previously. Approximately $0.15 \mathrm{~g}$ of dry tissue was weighed and placed in a Teflon vessel. Three milliliter of $7.5 \mathrm{~m} \mathrm{KOH}$ was added, and the solutions were heated in a programmable microwave as described. After cooling, $2 \mathrm{~mL}$ of hydrogen peroxide was added and the solutions were reheated. After the second heating event, $10 \mathrm{~mL}$ of 18 $\mathrm{M} \Omega$ water was added and then the solutions were filtered. Finally, a $1 \mathrm{~mL}$ aliquot of solution was diluted with $9 \mathrm{~mL}$ of $18 \mathrm{M} \Omega$ water and analyzed using ICP-OES.

The experimental design was completely randomized, and each species was analyzed separately. Data were subjected to analysis of variance using SAS 9.3 (SAS Institute, Inc., Cary, NC). Means were separated with Tukey's honest significant difference test.

\section{Results and Discussion}

The incorporation of rice hulls to the soilless substrate did not affect flowering for sunflower or petunia. No significant differences in flower number (petunia) or days to flower occurred when $20 \%$ rice hulls were added to the substrate (Tables 2 and 3). Previously, we found that Si supplementation, provided as continuous $2 \mathrm{~mm}$ potassium silicate fertilization, hastened flowering in sunflower 'Pacino Gold' and increased flower number in petunia 'Dreams 
Table 2. Plant growth and tissue silicon (Si) of petunia (Petunia $\times$ hybrida 'Dreams Pink') grown in an 85 sphagnum peat: 15 perlite soilless substrate amended with $0 \%$ or $20 \%$ rice hulls (by volume).

\begin{tabular}{|c|c|c|c|c|}
\hline & \multicolumn{2}{|c|}{$\%$ rice hulls } & \multirow[b]{2}{*}{$\mathrm{HSD}^{\mathrm{z}}$} & \multirow[b]{2}{*}{$P$ value } \\
\hline & 0 & 20 & & \\
\hline Days to flower & 42.7 & 41.6 & - & 0.0748 \\
\hline Flower number & 19.2 & 17.6 & - & 0.1113 \\
\hline Leaf dry weight (g) & 2.68 & 2.10 & 0.21 & $<0.0001$ \\
\hline Stem dry weight (g) & 3.85 & 3.30 & 0.32 & 0.0012 \\
\hline Flower dry weight $(\mathrm{g})$ & 1.16 & 1.10 & - & 0.3756 \\
\hline Root dry weight (g) & 0.25 & 0.30 & - & 0.0537 \\
\hline Aboveground dry weight (g) & 7.69 & 6.50 & 0.54 & $<0.0001$ \\
\hline Total dry weight (g) & 7.94 & 6.80 & 0.57 & 0.0002 \\
\hline Leaf Si (mg. $\left.\mathrm{kg}^{-1}\right)$ & 946.3 & $2,036.2$ & 315.7 & $<0.0001$ \\
\hline Stem Si $\left(\mathrm{mg} \cdot \mathrm{kg}^{-1}\right)$ & 146.4 & 300.6 & 55.5 & $<0.0001$ \\
\hline Flower Si $\left(\mathrm{mg} \cdot \mathrm{kg}^{-1}\right)$ & 232.0 & 247.1 & - & 0.7918 \\
\hline Root Si $\left(\mathrm{mg} \cdot \mathrm{kg}^{-1}\right)$ & 157.2 & $1,237.0$ & 637.1 & 0.0015 \\
\hline Leaf Si (mg/plant) & 2.50 & 4.16 & 0.66 & $<0.0001$ \\
\hline Stem Si (mg/plant) & 0.57 & 0.98 & 0.21 & 0.0003 \\
\hline Flower Si (mg/plant) & 0.27 & 0.28 & - & 0.2537 \\
\hline Root Si (mg/plant) & 0.04 & 0.36 & 0.17 & 0.0006 \\
\hline Aboveground Si (mg/plant) & 3.34 & 5.42 & 0.64 & $<0.0001$ \\
\hline Total Si (mg/plant) & 3.38 & 5.78 & 0.69 & $<0.0001$ \\
\hline
\end{tabular}

zTukey's HSD value $(\alpha=0.05)$.

$\mathrm{HSD}=$ honestly significant difference

Table 3. Plant growth and tissue silicon (Si) of sunflower (Helianthus annuus 'Pacino Gold') grown in an 85 sphagnum peat: 15 perlite soilless substrate amended with $0 \%$ or $20 \%$ rice hulls (by volume).

\begin{tabular}{|c|c|c|c|c|}
\hline & \multicolumn{2}{|c|}{$\%$ rice hulls } & \multirow[b]{2}{*}{$\mathrm{HSD}^{\mathrm{z}}$} & \multirow[b]{2}{*}{$P$ value } \\
\hline & 0 & 20 & & \\
\hline Days to flower & 63.7 & 65.1 & - & 0.2553 \\
\hline Leaf dry weight (g) & 2.42 & 2.20 & 0.14 & 0.0022 \\
\hline Stem dry weight (g) & 2.89 & 2.65 & - & 0.1452 \\
\hline Flower dry weight $(\mathrm{g})$ & 3.57 & 2.99 & 0.46 & 0.0144 \\
\hline Root dry weight (g) & 1.15 & 1.03 & - & 0.0930 \\
\hline Aboveground dry weight $(\mathrm{g})$ & 8.87 & 7.83 & 0.41 & $<0.0001$ \\
\hline Total dry weight $(\mathrm{g})$ & 10.02 & 8.86 & 0.44 & $<0.0001$ \\
\hline Leaf Si $\left(\mathrm{mg} \cdot \mathrm{kg}^{-1}\right)$ & $1,260.1$ & $10,909.9$ & $1,129.1$ & $<0.0001$ \\
\hline Stem $\mathrm{Si}\left(\mathrm{mg} \cdot \mathrm{kg}^{-1}\right)$ & 42.7 & 303.5 & 20.5 & $<0.0001$ \\
\hline Flower Si $\left(\mathrm{mg} \cdot \mathrm{kg}^{-1}\right)$ & 41.2 & 252.3 & 37.5 & $<0.0001$ \\
\hline Root Si $\left(\mathrm{mg} \cdot \mathrm{kg}^{-1}\right)$ & 174.1 & 895.1 & 19.9 & $<0.0001$ \\
\hline Leaf Si (mg/plant) & 3.05 & 23.76 & 2.22 & $<0.0001$ \\
\hline Stem Si (mg/plant) & 0.13 & 0.82 & 0.24 & $<0.0001$ \\
\hline Flower Si (mg/plant) & 0.14 & 0.77 & 0.08 & $<0.0001$ \\
\hline Root Si (mg/plant) & 0.21 & 0.95 & 0.25 & $<0.0001$ \\
\hline Aboveground Si (mg/plant) & 3.32 & 25.35 & 2.47 & $<0.0001$ \\
\hline Total Si (mg/plant) & 3.53 & 26.30 & 2.60 & $<0.0001$ \\
\hline
\end{tabular}

zukey's HSD value $(\alpha=0.05)$.

$\mathrm{HSD}=$ honestly significant difference

Pink' across a range of $\mathrm{P}$ concentrations (Boldt et al., 2015), but that did not occur in the present study. Kamenidou et al. (2010) observed earlier flowering in gerbera (Gerbera hybrid L. 'Acapella') when supplemental $\mathrm{Si}$ was provided as rice husk ash substrate incorporation, hydrous potassium silicate substrate incorporation, or weekly sodium silicate foliar sprays, but not weekly potassium silicate drenches. However, although Kamenidou et al. (2008) noted no impact on days to flower for sunflower 'Ring of Fire' when rice husk ash or hydrous potassium silicate was incorporated into the soilless substrate or sodium silicate was supplied as a weekly foliar spray, the application of weekly potassium silicate drenches delayed anthesis by $3-5 \mathrm{~d}$ as the concentration of $\mathrm{Si}$ supplied increased from 50 to $200 \mathrm{mg} \cdot \mathrm{L}^{-1}$, respectively. These differing results across studies may be because of the Si source, Si concentration supplied, or concentration of plant-available $\mathrm{Si}$, as differences in aboveground dry weight in the present study may be due to changes to the chemical and physical properties of the soilless substrate due to the incorporation of $20 \%$ rice hulls rather than from Si supplementation, factors which are confounded. For example, Evans and Gachukia (2004) observed lower shoot dry weights in tomato (Lycopersicon esculentum Mill. 'Better Boy') and pansy (Viola ×wittrockiana 'Bingo Azure') when parboiled rice hulls were substituted for perlite in a peat substrate. In spite of the statistically significant differences in tissue dry weights in our study, they were not large enough to affect plant quality, and all plants were commercially acceptable.

In almost every instance, tissue from plants grown in the rice hull-amended substrate had a higher $\mathrm{Si}$ concentration compared with those grown in a nonamended substrate. The exception was petunia flowers, which had similar Si concentrations (232 and 247 $\mathrm{mg} \cdot \mathrm{kg}^{-1}$ in nonamended and amended substrates, respectively; Table 2). Silicon concentration was greatest in leaf tissue for both species. Sunflower, classified as a $\mathrm{Si}$ accumulator, had higher leaf Si concentrations than petunia, a low $\mathrm{Si}$ accumulator $(10,909$ and $2036 \mathrm{mg} \cdot \mathrm{kg}^{-1}$, respectively). In sunflower, a comparison of $\mathrm{Si}$ concentration revealed leaves had the greatest $\mathrm{Si}$ concentration, and roots, stems, and flowers had similar $\mathrm{Si}$ concentrations, regardless of $\mathrm{Si}$ treatment (statistics not shown). A similar pattern was observed in petunia in nonamended plants. In rice hull-amended petunia, however, Si concentration was greatest in leaves, then roots, followed by stems and flowers.

Differences in Si concentration between nonamended and rice hull-amended plants highlights differential $\mathrm{Si}$ accumulation and distribution between sunflower and petunia. The addition of rice hulls to the substrate increased Si concentration considerably in all sunflower tissues: $414 \%$ in roots, $512 \%$ in flowers, $611 \%$ in stems, and $766 \%$ in leaves. In petunia, however, aboveground $\mathrm{Si}$ concentration did not increase to the same degree; it only increased $7 \%$ in flowers, $105 \%$ in stems, and $115 \%$ in leaves. This is characteristic of nonaccumulators, which do not accumulate high concentrations of $\mathrm{Si}$ in foliar tissue, even when $\mathrm{Si}$ is amply available. Although nonaccumulators often exhibit an increase in foliar Si concentration in response to biotic or abiotic stress, foliar uptake is still typically much less than in $\mathrm{Si}$ accumulator species. However, the addition of rice hulls to the substrate resulted in a $687 \%$ increase in root Si concentration of petunia, from 157 to 1237 $\mathrm{mg} \cdot \mathrm{kg}^{-1}$ (Table 2). Lewin and Reimann (1969) observed a similar phenomenon and reported that plants with a high $\mathrm{Si}$ content most often accumulate it in the aerial portion, whereas plants with low $\mathrm{Si}$ accumulation may have root $\mathrm{Si}$ content equal to or greater than shoot Si content.

Silicon tends to move in the transpiration stream and accumulate at the terminus in 
plants, i.e., in leaves, panicles, and grains (Yoshida et al., 1962). Although evapotranspirational water loss via flowers is less than that via leaves, it is a source of water loss. Galen et al. (1999) reported that flower buds and corollas are a source of water loss in Polemonium viscosum, averaging 0.036 and $0.024 \mathrm{~g}$ of water per flower per hour at the bud phase and at maturity, respectively. Whiley et al. (1988) observed that evapotranspiration in avocado (Persea americana cv. Fuerte) flowers was $60 \%$ of that of leaves, and $\approx 13 \%$ of total canopy water loss resulted from floral organs. Therefore, flowers could potentially accumulate high concentrations of Si. Sunflower inflorescences did indeed exhibit increased $\mathrm{Si}$ accumulation when plants were grown in the rice hull-amended substrate, compared with the nonamended substrate ( 252 vs. $41 \mathrm{mg} \cdot \mathrm{kg}^{-1}$, respectively; Table 3). Petunia, however, did not show this response ( 247 vs. $232 \mathrm{mg} \cdot \mathrm{kg}^{-1}$, respectively; Table 2). One plausible explanation may be the fact that sunflowers have a primary inflorescence that remains on the plant for a couple of weeks before senescence, whereas petunia flowers are short-lived in comparison, often lasting only a day or two. This may not be sufficient time to accumulate $\mathrm{Si}$ in the flowers.

We were interested in Si accumulation in various plant tissues and the potential implications for biotic and abiotic stress tolerance. Plants often accumulate elevated foliar $\mathrm{Si}$ concentrations in response to stress (Frantz et al., 2011; Zellner et al., 2011). Although Si is not very mobile in the plant once deposited in leaves or other aerial portions of the plant (Yoshida et al., 1962), it is currently not clear if plants need to take up additional Si from the soil, substrate, or nutrient solution at the onset of a stress or if they can export some or all of the accumulated Si contained in the roots. It was somewhat surprising that roots of petunia, a nonaccumulator, had a greater Si concentration than roots of sunflower, a Si accumulator, because most of the focus on defining plants as $\mathrm{Si}$ accumulators or nonaccumulators is based on foliar Si concentration.

It has previously been shown that $\mathrm{Si}$ can mitigate botrytis infection in greenhousegrown crops. Supplying $0.67 \mathrm{~mm} \mathrm{Si}$ in a hydroponic nutrient solution reduced the leaf area infected by botrytis $3 \mathrm{~d}$ postinoculation in lettuce (Lactuca sativa L.), tomato, and pepper (Capsicum annuum L.) (Pozo et al., 2015). Flowers are susceptible to botrytis infection, especially during transport from the greenhouse to the final retail destination. Therefore, if flowers accumulated $\mathrm{Si}$ (with or without disease pressure), it could be evaluated as a potentially useful disease management strategy. Based on our results, however, petunia flowers did not exhibit increased $\mathrm{Si}$ concentrations when grown in a Si-amended substrate in the absence of disease pressure from botrytis. Sunflower did exhibit increased inflorescence $\mathrm{Si}$ accumulation, but it was very low compared with foliar $\mathrm{Si}$ concentration. Follow-up studies would be needed to determine what concentration of floral Si is necessary to deter botrytis infection, if $\mathrm{Si}$ in roots can be mobilized to flowers following infection, and whether the presence of botrytis can result in increased Si uptake.

In addition to observing $\mathrm{Si}$ accumulation in plants grown in a $\mathrm{Si}$-amended substrate, the internal distribution of $\mathrm{Si}$ was also of interest. Silicon content (g/plant) varied with treatment. Nonamended and rice hullamended petunias accumulated, on average, 3.38 and $5.78 \mathrm{~g} \mathrm{Si}$ per plant, respectively, whereas sunflowers accumulated 3.53 and $26.30 \mathrm{~g}$ Si per plant, respectively. Silicon was distributed predominantly in leaf tissue, although it varied with species. In rice hullamended petunia, the distribution was $72 \%$ in leaves, $17 \%$ in stems, $6 \%$ in roots, and $5 \%$ in flowers. In rice hull-amended sunflower, $\mathrm{Si}$ content was distributed $91 \%$ in leaves, $3 \%$ in stems, $3 \%$ in roots, and $3 \%$ in flowers (calculated from Tables 2 and 3 ). This differs from the aboveground distribution reported by Jones and Handreck (1967) for oat, a monocot and $\mathrm{Si}$ accumulator, which accumulated almost $41 \%$ of total $\mathrm{SiO}_{2}$ in inflorescences, $28 \%$ in leaf blades, $17 \%$ in leaf sheaths, $11 \%$ in culms, and less than $1 \%$ in caryopses.

Leachate Si concentration was 3.28 and $15.69 \mathrm{mg} \cdot \mathrm{L}^{-1}$ for petunias grown in nonamended and rice hull-amended substrates, respectively, and 0.42 and $2.06 \mathrm{mg} \cdot \mathrm{L}^{-1}$, respectively, for sunflowers. The lower leachate $\mathrm{Si}$ concentration for sunflower, relative to petunia, was likely the result of increased plant Si uptake (26.30 g for sunflower and $5.78 \mathrm{~g}$ for petunia) and depletion of the $\mathrm{Si}$ pool in the substrate solution. Silicon supplementation was supplied by the addition of rice hulls. Sphagnum peat also supplies low concentrations of plant-available $\mathrm{Si}$ to the substrate solution, as evidenced by Si present in the leachates of the nonamended treatments (Table 4). Frantz et al. (2010) reported less than $1 \mathrm{mg}$ Si extracted per liter of water per gram of sphagnum peat mix, whereas parboiled rice hulls released more than $8 \mathrm{mg}$ of $\mathrm{Si}$ per liter of water per gram of rice hulls. In an analysis of total $\mathrm{Si}$ following complete digestion, they reported $498 \mathrm{mg} \cdot \mathrm{kg}^{-1} \mathrm{Si}$ in sphagnum peat mix and $75,468 \mathrm{mg} \cdot \mathrm{kg}^{-1}$ in parboiled rice hulls (Frantz et al., 2010). Their $\mathrm{Si}$ concentration reported for rice hulls corresponds closely to the total Si concentration we measured for the batch of rice hulls used in our study $\left(76,010 \mathrm{mg} \cdot \mathrm{kg}^{-1}\right.$; Table 1$)$. This calculates to the addition of $956 \mathrm{mg}$ Si per container, although not all of the $\mathrm{Si}$ is immediately soluble and plant available.

Leachate $\mathrm{pH}$ was similar between rice hull-amended and nonamended treatments for petunia and sunflower (Table 4). Electrical conductivity of sunflower leachates was higher in the nonamended treatment compared with the rice hull-amended treatment (3.58 and $3.07 \mathrm{mS} \cdot \mathrm{cm}^{-1}$, respectively), whereas EC was similar in petunia across both treatments $\left(0.93\right.$ and $0.94 \mathrm{mS} \cdot \mathrm{cm}^{-1}$, respectively). These EC values were less than (petunia) or within (sunflower) the optimal range of $2.0-3.5 \mathrm{mS} \cdot \mathrm{cm}^{-1}$ (Cavins et al., 2000). Although leachate EC values were low for petunia, both treatments had similar foliar $\mathrm{N}$ concentrations and were within the recommended range (Table 5), indicating adequate fertilizer rates. There were some sporadic and inconsequential differences in other foliar nutrient concentrations, as well as some foliar nutrient concentrations falling less than published recommended ranges (Gibson et al., 2007). Petunia foliar S and $\mathrm{Zn}$ concentrations were lower than recommended in both treatments, and foliar $\mathrm{K}$ and $\mathrm{Cu}$ concentrations were lower than recommended in the non-amended treatment only. Sunflower foliar $\mathrm{N}, \mathrm{K}$, and $\mathrm{Cu}$ were lower than recommended in both treatments. Despite differences and some nutrients being less than recommended ranges, there were no visual symptoms of nutrient deficiency in either species.

In addition to $\mathrm{Si}$, leachates differed in concentration for many macro- and micronutrients (Table 4). For example, leachates

Table 4. Leachate ${ }^{\mathrm{z}} \mathrm{pH}$, electrical conductivity (EC), silicon (Si), macronutrient, and micronutrient concentrations of petunia (Petunia $\times$ hybrida 'Dreams Pink') and sunflower (Helianthus annuus 'Pacino Gold') grown in an 85 sphagnum peat: 15 perlite soilless substrate amended with $0 \%$ or $20 \%$ rice hulls (by volume).

\begin{tabular}{|c|c|c|c|c|c|c|c|c|c|c|c|c|c|c|}
\hline \multirow[b]{2}{*}{ Plant } & \multirow[b]{2}{*}{ Rice hull (\%) } & \multirow[b]{2}{*}{$\mathrm{pH}$} & \multirow[b]{2}{*}{$\mathrm{EC}\left(\mathrm{mS} \cdot \mathrm{cm}^{-1}\right)$} & $\mathrm{Si}$ & $\mathrm{P}$ & $\mathrm{K}$ & $\mathrm{Ca}$ & $\mathrm{Mg}$ & $\mathrm{S}$ & $\mathrm{B}$ & $\mathrm{Cu}$ & $\mathrm{Fe}$ & $\mathrm{Mn}$ & $\mathrm{Zn}$ \\
\hline & & & & \multicolumn{11}{|c|}{ 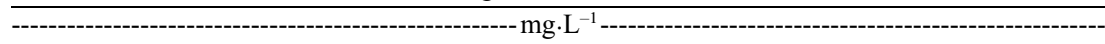 } \\
\hline \multirow[t]{3}{*}{ Petunia } & 0 & 5.66 & 0.93 & 3.28 & 47.4 & 138.9 & 429.9 & 125.6 & 5.56 & 0.14 & 0.08 & 13.61 & 0.61 & 1.13 \\
\hline & 20 & 5.59 & 0.94 & 15.69 & 45.1 & 184.0 & 331.5 & 101.3 & 4.03 & 0.14 & 0.10 & 9.71 & 1.21 & 1.24 \\
\hline & $\mathrm{HSD}^{\mathrm{y}}$ & - & - & 1.86 & - & 40.2 & 66.5 & 20.6 & 0.85 & - & - & 2.23 & 0.21 & - \\
\hline \multirow[t]{3}{*}{ Sunflower } & 0 & 4.87 & 3.58 & 0.42 & 44.3 & 31.9 & 105.3 & 35.3 & 3.36 & 0.20 & 0.08 & 4.40 & 0.16 & 0.84 \\
\hline & 20 & 4.79 & 3.07 & 2.06 & 49.6 & 31.0 & 98.7 & 36.5 & 1.93 & 0.24 & 0.06 & 2.73 & 0.39 & 0.64 \\
\hline & HSD & - & 0.46 & 0.47 & - & - & - & - & 0.40 & 0.03 & 0.01 & 0.60 & 0.08 & 0.08 \\
\hline
\end{tabular}

${ }^{\mathrm{z}}$ Leachates were collected at the end of the experiment, 6 weeks after transplant.

${ }^{\mathrm{y}}$ Tukey's HSD value $(\alpha=0.05)$. If the value is not provided, ANOVA $P$-value $>0.05$.

$\mathrm{HSD}=$ honestly significant difference; ANOVA = analysis of variance 
Table 5. Foliar macronutrient (\% dry weight) and micronutrient $\left(\mathrm{mg} \cdot \mathrm{L}^{-1}\right)$ concentration of petunia (Petunia $\times$ hybrida 'Dreams Pink') and sunflower $($ Helianthus annuus 'Pacino Gold') grown in an 85 sphagnum peat: 15 perlite soilless substrate amended with $0 \%$ or $20 \%$ rice hulls (by volume).

\begin{tabular}{|c|c|c|c|c|c|c|c|c|c|c|c|c|c|}
\hline \multirow[b]{2}{*}{ Plant } & \multirow[b]{2}{*}{ Rice hull (\%) } & $\mathrm{N}$ & $\mathrm{P}$ & $\mathrm{K}$ & $\mathrm{Ca}$ & $\mathrm{Mg}$ & $\mathrm{S}$ & B & $\mathrm{Cu}$ & $\mathrm{Fe}$ & $\mathrm{Mn}$ & Mo & $\mathrm{Zn}$ \\
\hline & & \multicolumn{6}{|c|}{ 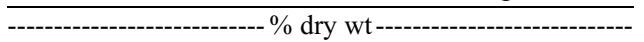 } & \multicolumn{6}{|c|}{ 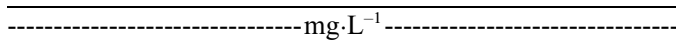 } \\
\hline Petunia & 20 & 5.76 & 0.91 & 3.83 & 3.31 & 1.21 & 0.20 & 23.9 & 10.5 & 111.4 & 145.7 & 7.1 & 31.3 \\
\hline \multirow[t]{3}{*}{ Sunflower } & 0 & 4.92 & 1.13 & 3.08 & 4.58 & 1.18 & 0.25 & 116.0 & 1.9 & 136.0 & 122.4 & 2.8 & 98.6 \\
\hline & 20 & 4.88 & 1.22 & 2.89 & 5.19 & 1.21 & 0.22 & 141.5 & 2.5 & 106.4 & 259.9 & 6.0 & 100.6 \\
\hline & HSD & - & 0.06 & - & 0.32 & - & 0.01 & 7.8 & 0.6 & 16.4 & 16.1 & 0.8 & - \\
\hline
\end{tabular}

${ }^{\mathrm{z}}$ Tukey's HSD value $(\alpha=0.05)$. If the value is not provided, ANOVA $P$-value $>0.05$.

$\mathrm{HSD}=$ honest significant difference; ANOVA $=$ analysis of variance.

from rice hull-amended substrates in which petunias were grown had higher concentrations of $\mathrm{K}$ and $\mathrm{Mn}$ and lower concentrations of $\mathrm{Ca}, \mathrm{Mg}, \mathrm{S}$, and $\mathrm{Fe}$. Leachates from rice hull-amended substrates in which sunflowers were grown had higher concentrations of $\mathrm{B}$ and $\mathrm{Mn}$, and lower concentrations of $\mathrm{S}, \mathrm{Cu}$, $\mathrm{Fe}$, and $\mathrm{Zn}$. As stated previously, this may be attributable to the nutrient composition of the rice hulls or to the influence of $\mathrm{Si}$ on the uptake of other macro- and micronutrients. In a previous study, the addition of $10 \%$ parboiled rice hulls to a sphagnum peat: perlite substrate resulted in increased concentrations of $\mathrm{P}, \mathrm{K}, \mathrm{B}$, and $\mathrm{Mn}$ and a lower concentration of $\mathrm{S}$ in leachate samples compared with the nonamended control, all of which were also observed in either petunia or sunflower leachate samples in our present study (J.E. Altland and J.C. Locke, unpublished data).

\section{Conclusions}

This study quantified Si accumulation and distribution in roots, stems, leaves, and flowers of two ornamental plant species. It revealed that $\mathrm{Si}$ concentration, as well as $\mathrm{Si}$ content, varied considerably with species and tissue. Silicon accumulator and nonaccumulator species, although having very different foliar concentrations, can have similar root $\mathrm{Si}$ concentrations, as was observed for sunflower and petunia in this study. Therefore, classifying species as $\mathrm{Si}$ accumulators or nonaccumulators solely on the basis of foliar Si concentration does not necessarily provide a complete picture of total plant $\mathrm{Si}$ accumulation and uptake capacity. The localization of Si within a plant could potentially influence its ability to effectively mitigate stress events (e.g., floral Si accumulation may provide control of botrytis whereas root accumulation may provide control of pythium), but follow-up studies will be needed to test this hypothesis.

\section{Literature Cited}

Agarie, S., N. Hanaoka, O. Ueno, A. Miyazaki, F. Kubota, W. Agata, and P.B. Kaufman. 1998. Effects of silicon on tolerance to water deficit and heat stress in rice plants (Oryza sativa L.), monitored by electrolyte leakage. Plant Prod. Sci. 1:96-103.

Boldt, J., J. Altland, W. Zellner, and J. Locke. 2015. Silicon improves flowering characteristics of sunflower and petunia at low phosphorus rates. HortScience 50:S142 (abstr.).
Cavins, T.J., B.E. Whipker, W.C. Fonteno, B. Harden, I. McCall, and J.L. Gibson. 2000. Monitoring and managing $\mathrm{pH}$ and EC using the PourThru extraction method. Hort. Info. Lflt. 590. NC State Univ.

Chain, F., C. Côté-Beaulieu, F. Belzile, J.G. Menzies, and R.R. Bélanger. 2009. A comprehensive transcriptomic analysis of the effect of silicon on wheat plants under control and pathogen stress conditions. Mol. Plant Microbe Interact. 22:1323-1330.

Datnoff, L.E., C.W. Deren, and G.H. Snyder. 1997. Silicon fertilization for disease management of rice in Florida. Crop Protection 16:525-531.

Epstein, E. 1999. Silicon. Annu. Rev. Plant Physiol. Plant Mol. Biol. 50:641-664.

Evans, M.R. and M. Gachukia. 2004. Fresh parboiled rice hulls serve as an alternative to perlite in greenhouse crop substrates. HortScience 39:232-235.

Fauteux, F., F. Chain, F. Belzile, J.G. Menzies, and R.R. Bélanger. 2006. The protective role of silicon in the Arabidopsis-powdery mildew pathosystem. Proc. Natl. Acad. Sci. U.S.A. 103:17554-17559.

Frantz, J., J.C. Locke, D.S. Sturtz, and S. Leisner. 2010. Silicon in ornamental crops: Detection, delivery, and function, p. 111-134. In: F. Rodriguez (ed.). Silicio na agricultura: Anais do V simposio brasileiro sobre silicio agricultura. Universidade Federal de Viçosa, Viçosa, Brazil.

Frantz, J.M., S. Khandekar, and S. Leisner. 2011. Silicon differentially influences copper toxicity response in silicon-accumulator and nonaccumulator species. J. Amer. Soc. Hort. Sci. 136:329-338.

Galen, C., R.A. Sherry, and A.B. Carroll. 1999. Are flowers physiological sinks or faucets? Costs and correlates of water use by flowers of Polemonium viscosum. Oecologia 118:461-470.

Gibson, J.L., D.S. Pitchay, A.L. Williams-Rhodes, B.E. Whipker, P.V. Nelson, and J.M. Dole. 2007. Nutrient deficiencies in bedding plants: A pictorial guide for identification and correction. Ball Publishing, Batavia, IL.

Guével, M-H., J.G. Menzies, and R.R. Bélanger. 2007. Effect of root and foliar applications of soluble silicon on powdery mildew control and growth of wheat plants. Eur. J. Plant Pathol. 119:429-436.

Hattori, T., S. Inanaga, H. Araki, P. An, S. Morita, M. Luxová, and A. Lux. 2005. Application of silicon enhanced drought tolerance in Sorghum bicolor. Physiol. Plant. 123:459-466.

He, Y., H. Xiao, H. Wang, Y. Chen, and M. Yu. 2010. Effect of silicon on chilling-induced changes of solutes, antioxidants, and membrane stability in seashore Paspalum turfgrass. Acta Physiol. Plant. 32:487-494.

Ishiguro, K. 2001. Review of research in Japan on the roles of silicon in conferring resistance against rice blast. Studies Plant Sci. 8:277291.
Jones, L.H.P. and K.A. Handreck. 1967. Silica in soils, plants, and animals. Adv. Agron. 19:107149.

Kamenidou, S., T.J. Cavins, and S. Marek. 2008. Silicon supplements affect horticultural traits of greenhouse-produced ornamental sunflowers. HortScience 43:236-239.

Kamenidou, S., T.J. Cavins, and S. Marek. 2010. Silicon supplements affect floricultural quality traits and elemental nutrient concentrations of greenhouse produced gerbera. Scientia Hort. 123:390-394.

LeBude, A.V. and T.E. Bilderback. 2009. The Pour-Through extraction procedure: A nutrient management tool for nursery crops. North Carolina State Univ. Ext. AG-717-W.

Lewin, J. and B.E.F. Reimann. 1969. Silicon and plant growth. Annu. Rev. Plant Physiol. 20:289-304.

Li, J., S.M. Leisner, and J. Frantz. 2008. Alleviation of copper toxicity in Arabidopsis thaliana by silicon addition to hydroponic solutions. J. Amer. Soc. Hort. Sci. 133:670-677.

Liang, Y., H. Hua, Y-G. Zhu, J. Zhang, C. Cheng, and V. Römheld. 2006. Importance of plant species and external silicon concentration to active silicon uptake and transport. New Phytol. 172:63-72.

Liang, Y., Q. Shen, Z. Shen, and T. Ma. 1996. Effects of silicon on salinity tolerance of two barley cultivars. J. Plant Nutr. 19:173183.

Liang, Y., W. Sun, Y-G. Zhu, and P. Christie. 2007. Mechanisms of silicon-mediated alleviation of abiotic stresses in higher plants: A review. Environ. Pollut. 147:422-428.

Liang, Y., J. Zhu, Z. Li, G. Chu, Y. Ding, J. Zhang, and W. Sunday. 2008. Role of silicon in enhancing resistance to freezing stress in two contrasting winter wheat cultivars. Environ. Expt. Bot. 64:286-294.

Ma, J.F. 2004. Role of silicon in enhancing the resistance of plants to biotic and abiotic stresses. Soil Sci. Plant Nutr. 50:11-18.

Ma, J.F., Y. Miyake, and E. Takahashi. 2001. Silicon as a beneficial element for crop plants. Studies Plant Sci. 8:17-39.

Ma, J.F. and E. Takahashi. 2002. Soil, fertilizer, and plant silicon research in Japan. Elsevier Sci., Amsterdam, The Netherlands.

Ma, J.F. and N. Yamaji. 2006. Silicon uptake and accumulation in higher plants. Trends Plant Sci. 11:392-397.

Massey, F.P., A.R. Ennos, and S.E. Hartley. 2006. Silica in grasses as a defence against insect herbivores: Contrasting effects on folivores and a phloem feeder. J. Anim. Ecol. 75:595603.

Menzies, J., P. Bowen, D. Ehret, and A.D.M. Glass. 1992. Foliar applications of potassium silicate reduce severity of powdery mildew on cucumber, muskmelon, and zucchini squash. J. Amer. Soc. Hort. Sci. 117:902-905. 
Mitani, N. and J.F. Ma. 2005. Uptake system of silicon in different plant species. J. Expt. Bot. 56:1255-1261.

Pozo, J., M. Urrestarazu, I. Morales, J. Sánchez, M. Santos, F. Dianez, and J.E. Álvaro. 2015. Effects of silicon in the nutrient solution for three horticultural plant families on the vegetative growth, cuticle, and protection against Botrytis cinerea. HortScience 50:1447-1452.

Reynolds, O.L., M.G. Keeping, and J.H. Meyer. 2009. Silicon-augmented resistance of plants to herbivorous insects: A review. Ann. Appl. Biol. 155:171-186.
Romero-Aranda, M.R., O. Jurado, and J. Cuartero. 2006. Silicon alleviates the deleterious salt effect on tomato plant growth by improving plant water status. J. Plant Physiol. 163:847-855.

Savant, N.K., G.H. Korndörfer, L.E. Datnoff, and G.H. Snyder. 1999. Silicon nutrition and sugarcane production: A review. J. Plant Nutr. 22:1853-1903.

Whiley, A.W., K.R. Chapman, and J.B. Saranah. 1988. Water loss by floral structures of avocado (Persea americana cv. Fuerte) during flowering. Austral. J. Agr. Res. 39:457-467.
Yoshida, S., Y. Ohnishi, and K. Kitagishi. 1962. Chemical forms, mobility and deposition of silicon in rice plant. Soil Sci. Plant Nutr. $8: 15-21$.

Zellner, W., J. Frantz, and S. Leisner. 2011. Silicon delays Tobacco ringspot virus systemic symptoms in Nicotiana tabacum. J. Plant Physiol. 168:1866-1869.

Zhu, Y. and H. Gong. 2014. Beneficial effects of silicon on salt and drought tolerance in plants. Agron. Sustain. Dev. 34:455472 . 